\title{
ACRL Candidates, 1978 Elections
}

\section{ASIAN AND AFRICAN SECTION}

Vice-Chair/Chair-Elect

Y. T. Feng, Librarian, Wellesley College, Wellesley, MA 02181

Alice N. Loranth, Head, John G. White Department of Folklore, Orientalia and Chess, Cleveland Public Library, Cleveland, $\mathrm{OH} 44114$ Member-at-Large (three-year term)

E. Christian Filstrup, First Assistant, Oriental Division, The Research Libraries, New York Public Library, New York, NY 10018

Elizabeth A. Widenmann, Cataloger and African Bibliographer, Herbert Lehman Library, Columbia University, New York, NY 10027

\section{BIBLIOGRAPHIC INSTRUCTION SECTION}

Chair

Pamela J. Cravey, Reference Librarian and Assistant Professor, Pullen Library, Georgia State University, Atlanta, GA 30303

Sheila M. Laidlaw, Librarian, Sigmund Samuel Library, University of Toronto, Toronto, Ontario, Canada M5S 1 A5

Vice-Chair/Chair-Elect

Sharon Hogan, Reference Librarian and Bibliographical Instructor, Harlan Hatcher Graduate Library, University of Michigan, Ann Arbor, MI 48109

Brian T. Nielsen, Instructional Librarian, Undergraduate Library, University of North
Carolina at Chapel Hill, Chapel Hill, NC 27514 Secretary (one-year term)

Mignon Adams, Coordinator of Library Instruction, Penfield Library, State University of New York, College of Arts and Sciences, Oswego, NY 13126

Melissa M. Cain, Assistant Undergraduate Librarian, University of Illinois Library, Urbana, IL 61801

Member-at-Large (one-year term)

Louise P. Gerity, Bibliographic Instruction Librarian, Lewis and Clark College, Portland, OR 97219

Glenda S. Neely, Assistant Professor and Reference Librarian, University Library, University of Louisville, Louisville, KY 40208

Member-at-Large (two-year term)

Linda L. Lester, Public Services Librarian, Shafer Library, Findlay College, Findlay, OH 45840

Cleo Treadway, Director of Library Services, Tusculum College, Greenville, TN 37743

Member-at-Large (three-year term)

William W. Prince, General Reference Librarian, Carol M. Newman Library, Virginia Polytechnic Institute and State University, Blacksburg, VA 24061

Carla J. Stoffle, Assistant Director and Coordinator of Public Services, Library/Leaming Center, University of Wisconsin-Parkside, Kenosha, WI 53141

Preliminary List of Preconference

Institutes at ALA Chicago Conference, 1978

The following preconference institutes will be held:

UNIT TENTATIVE TITLE

ACRL

Study of Books as Physical

Objects. Rare Books and Manuscripts

TENTATIVE DATES

Section. New Haven, Conn.

LAD Nuts \& Bolts, Public Relations

ALSC and High Interest/Low Level Reading

YASD Materials for Junior and Senior

High School People

AASL Promoting Educational Equity:

Sexism Awareness for the

Many Media Specialists

ISAD

Library Automation-State of

the Art

LAD

Library Buildings and Energy

Conservation

LSD and SRRT Forgotten Disadvantaged-Rural,

Poor and Appalachian People

GODORT

Economics and Statistics

Available from the Bureau of June 21-24

June 21-23

June 23

the Census

June 23-24

June 23-24

June 23-24

June 23-24

June 21-23 